\title{
"Buying a Pig in a Poke": The Problem of Elasmobranch Meat Consumption in Southern Brazil
}

\author{
Hugo Bornatowski ${ }^{{ }^{*}}$, Raul Rennó Braga ${ }^{2}$, Carolina Kalinowski ${ }^{2}$, and Jean Ricardo Simões Vitule ${ }^{2}$ \\ Author Addresses: ${ }^{1}$ Instituto de Pesca, Avenida Av. Bartolomeu de Gusmão, 192, Santos, São Paulo, 11030-906, Brazil. \\ ${ }^{2}$ Laboratório de Ecologia e Conservação, DEA, Setor de Tecnologia, Universidade Federal do Paraná, Curitiba 19020, Brazil. \\ *Corresponding author: anequim.bio@gmail.com
}

Received: July 16, 2015

Volume: 6(1):196-202

Published: November 18, 2015

(C) 2015 Society of Ethnobiology

\begin{abstract}
In Brazil, the demand for sustainably certified seafood is increasing and retailers have promised to source all seafood from sustainable sources by 2015. In the southern portion of the country, elasmobranch meat is sold as cação, and consumers are often unaware that cação refers to any type of elasmobranch. The present study used questionnaires to investigate the lay public's knowledge of elasmobranch meat sold in a Brazilian city. Shoppers were surveyed at supermarkets in Curitiba, the largest city in southern Brazil. The study revealed that people do not link commercialized cação meat to sharks and rays (Elasmobranchii), with more than half of respondents who claimed to have already eaten cação did not think they had ever eaten shark or ray. The educational profile of interviewees suggests that this lack of knowledge may be even more common in other segments of Brazilian society. Therefore, we suggest that ecological information about elasmobranchs should be included in Brazilian elementary and high school curricula. Such a measure has the potential to modify behavior, create awareness, and stimulate responsibility throughout society, with the primary goal of reducing shark meat consumption and, ultimately, guaranteeing the long term conservation of marine resources.
\end{abstract}

Keywords: Conservation, Environmental education, Elasmobranchs, Fisheries management, Food mislabeling, Supermarkets

\section{Introduction}

Sharks, skates, and rays (Elasmobranchii) are widely distributed and comprise a group of approximately 1,100 species (Compagno 2005). Although the number of elasmobranchs is small compared to some other groups of vertebrates, they exhibit reproductive strategies that can be quite elaborate and complex (Wourms 1977), rivaling those of highly derived tetrapods (Carrier et al. 2004). Several reproductive characteristics of elasmobranchs, such as long generation times, slow growth rates and low reproductive rates (Cahmi et al. 1998), make them especially susceptible to overexploitation (Hall 1999) and extinction (Dulvy et al. 2014), and there is extensive evidence of population declines for several species worldwide (Heithaus et al. 2008; Worm et al. 2013). These declines may have grave consequences for human populations since elasmobranchs occupy high positions in food webs and, therefore, act as important regulators of lower trophic levels and play a fundamental role in marine ecosystems (e.g. Bornatowski et al. 2014a; Ferretti et al. 2008; Heithaus et al. 2008).
Fisheries have large impacts on marine ecosystems worldwide (e.g. Pauly et al. 2013; Worm et al. 2013), with overfishing serving as the primary threat to many marine organisms, including sharks and rays (Jackson et al. 2001). Elasmobranch populations, however, face a variety of additional threats, including habitat degradation, pollution, and climate change (e.g. Simpfendorfer et al. 2011). The estimated number of chondrichthyan fish threatened by extinction exceeds the number of birds and is comparable to mammals (Dulvy et al. 2014; Kyne et al. 2015).

Despite their ecological importance (Ferretti et al. 2010; Heithaus et al. 2008), sharks and rays remain an important protein source for poorer communities worldwide (WildAid 2007), with many communities in such countries as Mozambique, Costa Rica, India, Sri Lanka, Borneo, and Brazil depending on small-scale fisheries for subsistence. On the other hand, in many countries because shark meat is viewed as a lowquality meat, unlinking the name "shark" or "ray" from the commercialized meat is frequently necessary to overcome consumer prejudice (Bornatowski et al. 
2013, 2014b; Vannuccini 1999). Additionally, shark consumption is of great concern to human health because the meat contains high levels of heavy metals (lead and mercury) due to biomagnification (EscobarSánchez et al. 2011; Lopez et al. 2013; Pethybridge et al. 2000).

While the global shark fin trade has decreased since the 2000s, the shark meat (sharks and rays) trade increased by $42 \%$ from 2000 to 2011, with Brazil being a major importer of shark meat (Dent and Clarke 2015). Brazilian markets label shark meat as cação and restaurants also use cação rather than tubarão (shark) in identifying their dishes (Bornatowski et al. 2013). Consumers are often unaware that cação refers to shark and ray meat. This mislabeling may preclude people from taking health- and/or conservationrelated decisions concerning the consumption of elasmobranch meat and thus interfere with efforts to reduce consumption or redirect consumption towards non-threatened species (Barbuto et al. 2010; Bornatowski et al. 2013; Jacquet and Pauly 2008).

The purpose of the present study was to investigate by means of questionnaires the lay public's knowledge of elasmobranch meat sold as cação in a large city in southern Brazil. Our results highlight the poor state of knowledge in this region concerning this seafood. Additionally, the study may help advance efforts to inform consumers of the threatened status of elasmobranchs.

\section{Material and Methods}

We used semi-structured questionnaires to survey 104 individuals between June and October, 2014, at supermarkets in Curitiba. With 1.8 million inhabitants, Curitiba is one of the ten largest cities in Brazil, the largest city in the southern region, and has the fourth highest Human Development Index in Brazil (IBGE 2015). It is located nearly $110 \mathrm{~km}$ from the Atlantic Ocean, and therefore is a major market for the regional marine fishery. Individuals surveyed during the study were chosen from people in the fish section of the supermarkets on Saturday mornings between February and October 2014.

As part of the survey, we initially collected information regarding the sex, age, and education level of the interviewed person. Subsequently we asked questions to evaluate consumers' knowledge concerning shark meat. These questions were:

1) Do you eat fish?

2) Have you eaten cação meat?
3) Have you eaten shark meat?

4) Have you eaten ray meat?

5) To your knowledge, cação corresponds to which kind of animal? (More than one answer was possible: any fish species, a marine fish, a shark species, several fish species, a small or young shark, a boneless fish, and a ray species.)

6) What do you take into account when purchasing fish meat? (More than one answer was possible and the options were: health issues, environmental/ecological issues, taste, price, social issues involving fisheries, and knowledge of the meat's origin.)

7) Of the options given, which type of fish do you prefer to eat? Which do you eat most frequently? (More than one answer was possible. Options included Portuguese common names of fish that are commonly commercialized in Brazil: "salmon", "hake", "tilapia", "cação", "cod", and "flatfish".)

Two final questions were asked to evaluate the individual's basic knowledge of the issues surrounding the fishing and conservation of sharks and rays:

8) Why are sharks and rays fished? (More than one answer was possible and the options were: meat sale, fishing trophy, finning, meat exportation, gamefish, medicinal purpose, and to prevent shark attack.)

9) Did you know that $25 \%$ of elasmobranch species are under threat of extinction?

\section{Results}

Of the 104 respondents, 57\% were male and 43\% female. Regarding education level, $54 \%$ of respondents had an undergraduate or graduate degree, while $22 \%$ had not attained an undergraduate degree.

A high degree of inconsistency was observed when comparing responses given for shark, ray, and cação meat consumption. The majority of interviewees $(61 \%)$ claimed they ate cação but not shark, or ate rays but not cação $(56 \%)$ (Figure 1). In response to the question "caşão corresponds to which kind of animal?", $42 \%$ said that it is "a marine fish," $27 \%$ "a shark," 21\% "a small or young shark," and 10\% "any fish species."

The question "what do you take into account when purchasing fish meat?" revealed that the choice 


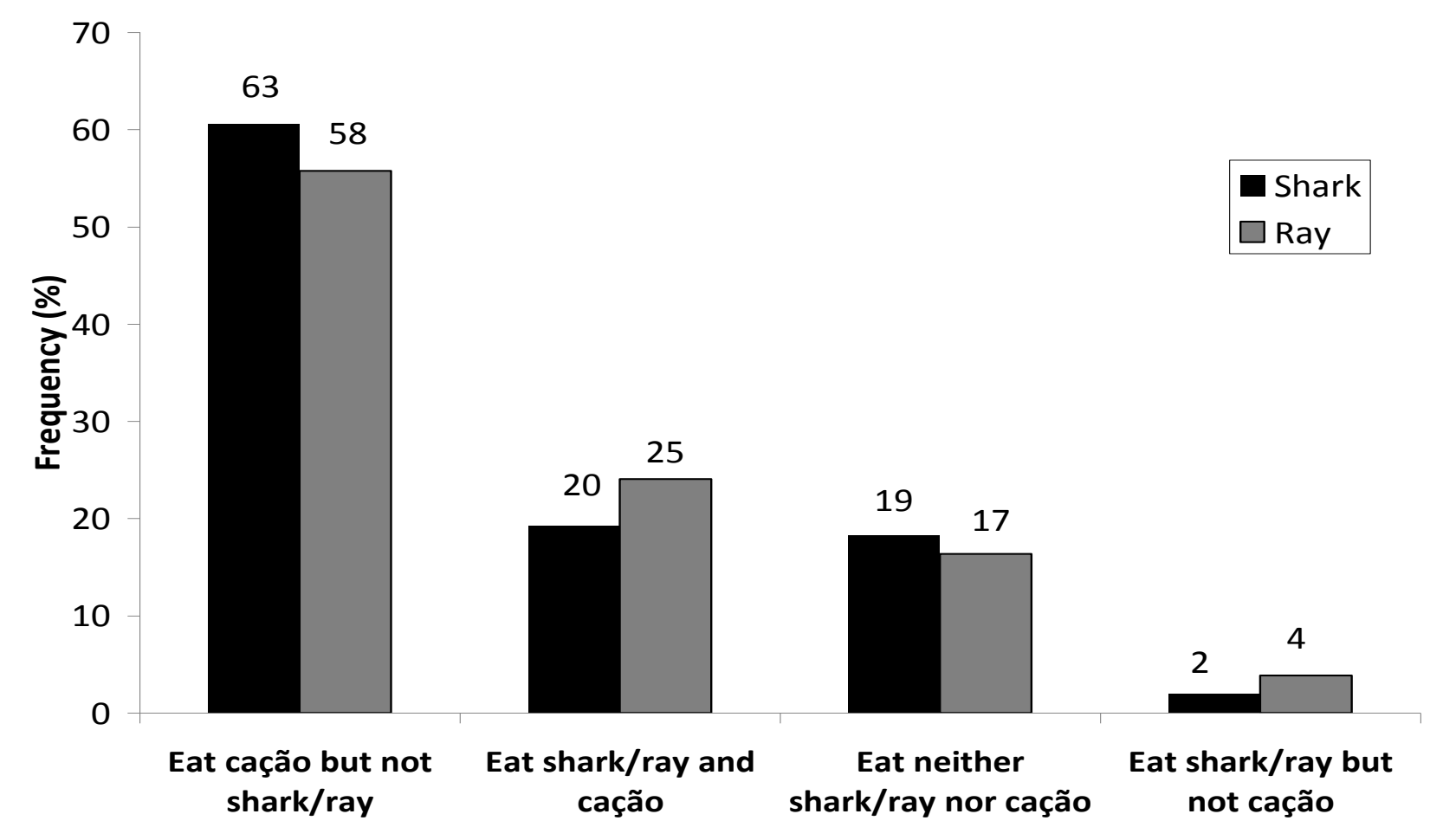

Figure 1. Questions that assessed the knowledge of respondents about shark/ray and cação meat consumption in southern Brazil.

of fish meat depends, mainly, on taste (100\%), followed by health issues (64\%), and cost of the meat $(20 \%)$. Only $12 \%$ indicated concern with the social issues involving fisheries.

Based on the question "which type of fish do you prefer to eat?", the most preferred fish was salmon $(69 \%)$, followed by tilapia (52\%), and flatfish (41\%). Cação was the least common response (18\%). The most consumed fish was salmon $(66 \%)$, followed by tilapia (49\%), and flatfish (23\%). Here again, cação was indicated least frequently (11\%).

In response to the question "why are sharks fished?", 66\% indicated for "meat sale," $46 \%$ for finning, and $28 \%$ for sport fishing. Additionally, $69 \%$ of respondents indicated they did not know that one quarter of elasmobranch species are under threat of extinction.

\section{Discussion}

Sharks attract attention and provoke curiosity because of their iconic nature, due in part to the fact that they are presented in the popular media as "dangerous" animals (Gross 2014). It seems, however, that there is considerable resistance to shark conservation, especially among the general public. Informing society about the ecological importance of sharks and rays and about the magnitude of the threat they currently face is paramount if we wish to increase the effectiveness of conservation measures by overcoming this resistance and correcting common misperceptions (Simpfendorfer et al. 2011).

A lack of appropriate labeling of seafood products is observed worldwide and threatens the society and ecological segments (Barbuto et al. 2010; Jacquet and Pauly 2008; Lamendin et al. 2015). Fish names are commonly replaced or adulterated by the fisheries and food industries, and people are often not capable of distinguishing between taxa because the meat is sliced and packaged prior to sale (Barbuto et al. 2010; Lamendin et al. 2015). Fraudulent representation or mislabeling of fish, including sharks and rays, has been recorded in some countries (e.g. Barbuto et al. 2010; Jacquet and Pauly 2008; Lamendin et al. 2015; Smith and Benson 2001; Wong and Hanner 2008), highlighting the impacts on the 
economy and ecosystem services (Jacquet and Pauly 2008).

The present study reveals that in the city of Curitiba, southern Brazil, many people do not link commercialized caşão meat with sharks and rays. Furthermore, about half of respondents who reported having eaten cação did not think they had ever eaten shark or ray. This inconsistency in fish consumers' responses demonstrates that they perceive cação to be some other type of marine fish. However, it was unclear as to which species that might be. The high level of education of interviewed people raises concern given that the scenario for the whole country might be even worse. Intentionally or not, attaching the name cação to any shark species (and to some rays) in commercial contexts in southern Brazil may impose a barrier to conservation measures addressing consumption of protected shark species (Jacquet and Pauly 2008). According to the Brazilian Consumer Protection Code ( $\mathrm{n}^{\circ}$ 8078/1990) (Brasil 1990), misleading product descriptions is a crime.

Responses regarding consumers' fish preferences demonstrate that despite being identified as cação to overcome consumer resistance on eating elasmobranch meat, it was still among the least preferred fish. Thus, correct labeling of elasmobranch meat as shark or ray could reduce its consumption in Brazil even further. On the other hand, because our results come from highly educated supermarket shoppers, as shown by our results on education level, in a large city in southern Brazil, further research is necessary to evaluate the consumption preferences of other cities and regions, as well as other segments of the Brazilian population. For example, as documented in other parts of the world (WildAid 2007), poorer communities in some coastal regions in Brazil may rely more on shark meat as a cost effective protein source than was documented in our study.

Actions taken to educate the lay public about the importance of shark conservation may not be effective in reducing the demand for shark meat and fins from the fisheries industry (Dell'Apa et al. 2014); this failure contributes to the continuation of high fishing pressure on sharks and rays (Dent and Clark 2015; Dulvy et al. 2014). This conclusion is corroborated by our results regarding what consumers take into account when choosing fish meat. Considering that nearly $20 \%$ of respondents expressed concern about environmental problems, increasing awareness of the ecological problems faced by sharks and rays might stimulate some people to avoid eating shark meat. However, some people may continue to eat cação if they are unaware that this word refers to shark meat. Therefore, certification programs such as the Marine Stewardship Council (MSC) and eco-labels, may help the consumers to choose more sustainable seafood products (Jacquet and Pauly 2008; Lamendin et al. 2015; Sampson et al. 2015; Von der Heyden et al. 2010). The establishment of speciesspecific commodity codes can facilitate trade monitoring of protected species, and also inform end consumers. Seven elasmobranchs were listed in the 2013 Convention on International Trade in Endangered Species of Wild Fauna and Flora - CITES Conference of Parties (CoP16) (i.e. Lamna nasus Bonnaterre Lamnidae, Carcharbinus longimanus Poey Carcharhinidae, Sphyrna lewini Griffith \& Smith Sphyrnidae, S. sygaena Linnaeus Sphyrnidae, $S$. mokarran Rüppell Sphyrnidae, and Manta spp. Bancroft Mobulidae). These species are found in southern Brazilian waters. With CITES oversight, the international trade of these species should only take place if the meat is shown to be obtained legally and sustainability. Knowledge of this should be available to consumers.

Ecological information provided through educational campaigns can promote long-term changes in people's awareness, environmental knowledge and attitude development (Cooke et al. 2013; Farmer et al. 2007; Van der Ploeg et al. 2010). On the other hand, the failure to engage the public in conservation and management issues can impede efforts to stem the biodiversity loss (Cooke et al. 2013). Therefore, we suggest that ecological information about sharks and rays, their role in ecosystems, and the risks to human health associated with their consumption due to high levels of heavy metals should be included in Brazilian elementary and high school curricula. Such a measure has the potential to modify behavior, create awareness, and stimulate responsibility throughout society, with the primary goal of reducing shark meat consumption and, ultimately, guaranteeing the long term conservation of marine resources. Unfortunately, because of the rapid decline of several shark populations worldwide, there is an urgent need for conservation actions (Dulvy et al. 2014). Thus, prompt implementation of labeling and educational campaigns is required to inform consumers which animals they are consuming and what are the associated risks. For instance, successful education 
campaigns in the Philippines transformed people's attitudes concerning crocodile conservation and led to the elimination of intentional crocodile killing (Van der Ploeg et al. 2010).

Modifying the behavior of all segments of elasmobranch commerce is essential for preventing ecological and social consequences (Jacquet and Pauly 2008). A key step in achieving such changes could be consumer pressure resulting from greater consumer awareness about the risks of consuming inadequately identified products. Potentially, this would cause supermarkets to buy only identified fish meat, which would in turn lead to the need for fish specialists to be present on fisheries landings. In addition, inspection by the Brazilian Institute of Environment and Renewable Natural Resources (IBAMA) should reinforce the supervision upon markets and sellers, especially after the recent publication, which identifies approximately $39 \%$ of Chondrichthyan species as threatened in Brazil (Peres et al. 2013).

Finally, the overall high educational profile of participants in our study suggests that lack of knowledge concerning cação may be even more common in segments of Brazilian society with lower education levels and other socioeconomic indicators. The next step should be conducting investigations about elasmobranch knowledge and consumption in other regions of Brazil. Although many consumers may be willing to consider the conservation consequences of their daily actions and food consumption, our study suggests they currently lack information necessary for making such decisions.

\section{Acknowledgments}

We thank Dr. James Nienow for reviewing our English.

\section{Declarations}

Permissions: None declared.

Sources of Funding: Bornatowski was supported by the São Paulo Research Foundation grants (FAPESP, process number 2013/25930-0); Kalinowski was supported by the National Council for Scientific and Technological Development (CNPq); Braga was supported financially by the Coordination for the Improvement of Higher Education Personnel (CAPES); Vitule was supported financially by the National Council for Scientific and Technological Development (CNPq).

Conflicts of Interest: None declared.

\section{References}

Barbuto, M., A. Galimberti, E. Ferri, M. Labra, R. Malandra, P. Galli and M. Casiraghi. 2010. DNA Barcoding Reveals Fraudulent Substitutions in Shark Seafood Products: The Italian Case of "palombo" (Mustelus spp.). Food Research International 43:376-381.

Bornatowski, H., R.R. Braga and J.R.S. Vitule. 2013. Shark Mislabeling Threatens Biodiversity. Science 340:923.

Bornatowski, H., A. F. Navia, R. R. Braga, V. Abilhoa and M.F.M. Corrêa. 2014a. Ecological Importance of Sharks and Rays in a Structural Foodweb Analysis in Southern Brazil. ICES Journal of Marine Science 71 (7):1586-1592.

Bornatowski, H., R. R. Braga and J. R. S. Vitule. 2014b. Threats to Sharks in a Developing Country: The Need for Effective and Simple Conservation Measures. Natureza \& Conservação 12(1):11-18.

Brasil. 1990. Lei n. 8.078, de 11 de setembro de 1990. Dispõe Sobre a Proteção do Consumidor e dá Outras Providências. Diário Oficial da República Federativa do Brasil, Brasília, DF, 12 set. 1990. Available at: http://www.planalto.gov.br/ccivil_03/ leis/18078.htm. Accessed on September 15, 2014.

Camhi, M., S. Fowler, J. Musick, A. Bräutigam and S. Fordham. 1998. Sharks and Their Relatives: Ecology and Conservation. Occasional Paper of the IUCN Species Survival Commission 20:63.

Carrier, J.C. H.L. Pratt and J.I. Castro. 2004. Reproductive Biology of Elasmobranchs. In Biology of sharks and their relatives, edited by J.C. Carrier, J.A. Musick and M.R. Heithaus, pp. 269-289. CRC, Boca Raton, FL.

Compagno, L., M. Dando and S. Fowler. 2005. Sharks of the World. Princeton University Press, Princeton, NJ.

Cooke, S.J., N.W.R. Lapointe, E.G. Martins, J.D. Thiem, G.D. Raby, M.K. Taylor, T.D. Beard and I.G. Cowx. 2013. Failure to Engage the Public in Issues Related to Inland Fishes and Fisheries: Strategies for Building Public and Political Will to Promote Meaningful Conservation. Journal of Fish Biology 83:997-1018.

Dell'Apa A., M.C. Smith and M.Y. Kaneshiro-Pineiro. 2014. The Influence of Culture on the International 
Management of Shark Finning. Environmental Management 54:151-161.

Dent, F. and S. Clarke. 2015. State of the Global Market for Shark Products. FAO Fisheries and Aquaculture Technical Paper No. 590. FAO, Rome, Italy.

Dulvy, N.K., L.R. Harisson, J.K. Carlson, L.N.K. Davidson, S.V. Forfham, M.P. Francis, C.M. Pollock, C.A. Simpfendorfer, G.H. Burgess, K.E. Carpenter, L.J.V. Compagno, D.A. Ebert, C. Gibson, M.R. Heupel, S.R. Livingstone, J.C. Sanciangco, J.D. Stevens, S. Valenti and W. T. White. 2014. Extinction Risk and Conservation of the World's Sharks and Rays. eLife 3:e00590.

Escobar-Sánchez, O., F. Galván-Magaña and R. Rosiles-Martínez. 2011. Biomagnification of Mercury and Selenium in Blue Shark Prionace glauca from the Pacific Ocean Off Mexico. Biological Trace Element Research 144:550-559.

Farmer, J., D. Knapp and G.M. Benton. 2007. An Elementary School Environmental Education Field Trip: Long-Term Effects on Ecological and Environmental Knowledge and Attitude Development. The Journal of Environmental Education 38:33-42.

Ferretti, F., B. Worm, G.L. Britten, M.R. Heithaus and H.K. Lotze. 2010. Patterns and Ecosystem Consequences of Shark Declines in the Ocean. Ecology Letters 13:1055-1071.

Gross, M. 2014. Learning to Live with Sharks. Current Biology 24(9):341-344.

Hall, S.J. 1999. Fish Biology and Aquatic Resources Series 1. Blackwell Science, Oxford, England.

Heithaus, M.R., A. Frid, A.J. Wirsing and B. Worm. 2008. Predicting Ecological Consequences of Marine Top Predator Declines. Trends in Ecology and Evolution 23(4):202-210.

Jacquet, J. L., and D. Pauly. 2008. Trade Secrets: Renaming and Mislabeling of Seafood. Marine Policy 32:309-318.

Jackson, J.B.C., M.X. Kirby, W.H. Berger, K.A. Bjorndal, L.W. Botsford, B.J. Bourque, R.H. Bradbury, R. Cooke, J. Erlandson, J.A. Estes, T.P. Hughes, S. Kidwell, C.B. Lange, H.S. Lenihan, J.M. Pandolfi, C.H. Peterson, R.S. Steneck, M.J. Tegner and T.R. Warner. 2001. Historical Overfishing and the Recent Collapse of Coastal Ecosystems. Science 293:629-638.

Kyne, P.M., N.J. Bax, and N.K. Dulvy. 2015. Biodiversity: Sharks and Rays in Peril Too. Nature 518:167.

Lamendin, R., K. Miller and R.D. Ward. 2015. Labelling Accuracy in Tasmanian Seafood: An Investigation using DNA Barcoding. Food Control 47:436-443.

Lopez, S.A., N.L. Abarca and R. Meléndez. 2013. Heavy Metal Concentrations of Two Highly Migratory Sharks (Prionace glauca and Isurus oxyrinchus) in the Southeastern Pacific Waters: Comments on Public Health and Conservation. Tropical Conservation Science 6:126-137.

Monroe, M. C., E. Andrews and K. Biedenweg. 2007. A Framework for Environmental Education Strategies. Applied Environmental Education \& Communication 6:205-216.

Pauly, D., R. Hilborn and T.A. Branch. 2013. Fisheries: Does Catch Reflect Abundance? Nature 494:303-306.

Pethybridge, H., D. Cossa and C.V. Butler. 2009. Mercury in 16 Demersal Sharks from Southeast Australia: Biotic and Abiotic Sources of Variation and Consumer Health Implications. Marine and Freshwater Research 68:18-26.

Peres, M.B., R.R. Barreto, R. Lessa, C. Vooren, P. Charvet and R. Rosa. 2013. Heavy Fishing Puts Brazilian Sharks and Rays in Great Trouble. World Fisheries Congress in Scotland. 6th World Fisheries Congress Sustainable Fisheries in a Changing World. Available at: http://sharkyear.com/2012/worldfisheries-congress-in-scotland.html. Accessed on October 15, 2015.

Sampson, G.S., J.N. Sanchirico, C.A. Roheim, S.R. Bush, J.E. Taylor, E.H. Allison, J.L. Anderson, N.C. Ban, R. Fujita, S. Jupiter and J.R. Wilson. 2015. Sustainability: Secure Sustainable Seafood from Developing Countries. Science 348(6234):504-506.

Simpfendorfer, C.A., M.R. Heupel, W.T. White and N.K. Dulvy. 2011. The Importance of Research and Public Opinion to Conservation Management of Sharks and Rays: A Synthesis. Marine and Freshwater Research 62:518-527. 
Smith, P.J. and P.G. Benson. 2001. Biochemical Identification of Shark Fins and Fillets from the Coastal Fisheries in New Zealand. Fishery Bulletin 99 (2):351-5.

Van der Ploeg, J., M. Cauilan-Cureg, M. van Weerd and W.T. De Groot. 2011. Assessing the Effectiveness of Environmental Education: Mobilizing Public Support for Philippine Crocodile Conservation. Conservation Letters 4:313-323.

Vannuccini, S. 1999. Shark Utilization and Trade. Food and Agriculture Organization technical paper, n.389, Rome, Italy.

Von der Heyden, S., J. Barendse, A.J. Seebregts and C.A. Matthee. 2010. Misleading the Masses: Detection of Mislabelled and Substituted Frozen Fish Products in South Africa. ICES Journal of Marine Science 67:176-185.

WildAid. 2007. The End of the Line? Global Threats to Sharks. Available at: www.wildaid.org. Accessed on March 10, 2015.

Worm, B., B. Davis, L. Kettemer, C.A. Ward-Paige, D. Chapman, M.R. Heithaus, S.T. Kessel and S.H.
Gruber. 2013. Global Catches, Exploitation Rates, and Rebuilding Options for Sharks. Marine Policy 40:194-204.

Wong, E.H.K. and R. Hanner. 2008. DNA Barcoding Detects Market Substitution in North American Seafood. Food Research International 41:828-837.

Wourms, J.P. 1977. Reproduction and Development in Chondrichthyan Fishes. American Zoologist 17:379_ 410.

\section{Biosketches}

Hugo Bornatowski works with biology and ecology of elasmobranchs. His research is focused on food webs and trophic modelling.

Raul Rennó Braga is a Ph.D. candidate conducting research on fish biology and ecology. He is particularly interested in aquatic invasions and trophic interactions.

Carolina Kalinowski is an undergraduate student interested in studies of elasmobranchs.

Jean Ricardo Simões Vitule is professor of zoology at the Universidade Federal do Paraná. His research is focused fish ecology, especially aquatic invasions. 